\title{
BREEDING FACILITIES FOR POLAR BEARS, THALARCTOS MARITIMUS (PHIPPS, 1774), IN CAPTIVITY
}

\author{
by \\ E. F. JACOBI \\ Royal Zoological Society Natura Artis Magistra, Amsterdam
}

\section{GENERAL INTRODUCTION}

All animals that bring forth helpless young care for them for a prolonged period in a concealed place. They come out of their "den" at an age of weeks or even months. In nature the pregnant female chooses the place to give birth. Its type and location depend on the kind of animal and the available possibilities. In all cases however, the mother feels completely safe and undisturbed in the chosen place and moves out with the young as soon as disturbing changes occur.

This same feeling of complete safety is necessary in captivity but mostly we arrange things and provide the shelter and, if any, the free choice of the female is very limited. If she does not feel safe fear will suppress her normal inborn nursing behaviour and the young will die.

The main reason of breeding problems in zoos with carnivorous and other animals that need a confined shelter for their young lays here. A difficulty is that we know little of the natural breeding habits of most species involved, the type of shelter, the connection with the male or other members of the group during this period etc. On the other hand we are helped by the flexibility of nature. If a female gets enough time to get used to our special arrangements she often will accept them even if she thinks them rather poor.

If the accommodation lacks some necessary features and is not accepted the following possibilities may occur:

a. The young are ignored;

b. Immediately after birth or afterwards (after immobility or death by cold?) the young are eaten;

c. The young are dragged around in search of a better place. This mostly ends in damaging, killing and eating the young.
Sometimes difficulties arise after one or more weeks of normal behaviour only. In all these cases, of course, zoo people try to secure the young and save them. We sometimes get the impression that a female after some failures gets "spoiled" and keeps to a fixed abnormal behaviour, whatever is changed in the facilities offered. Individual differences between females of one species play an important role in acceptance of the given facilities. Often they will be a result of the history of the female:

a. When the female is very tame or even "attached" to the keeper his influence and support can calm her down and make her accept even very poor accommodation. (A more natural behaviour, even of such a female, is aggressiveness at least during the first days after birth.) An animal afraid of people (an aggressive animal) will need quite different accommodation.

b. An animal reared solitarily by hand is often mentally defective and will not accept young or will even fail to breed. If brought up together with sisters and brothers there is less danger of damage but it is always better to have a youngster brought up naturally.

c. Good health and adequate feeding of the mother are also of paramount importance for a normal behaviour and a good health of the newborn young. If these are weak and do not behave normally this can be a cause of failure.

Other reasons given are, I think, mostly secondary or wishful thinking, as they protect the zoo people from blame. Not producing milk, hereditary causes (inbreeding after one or two generations!), misbehaviour (l), lack of practice (with first young) and so 
on have too often proved nonsense to be really accepted as sound biological causes. They are dangerous for good zoo management, as they blame the animal and not the real culprits: the responsible zoo people. Many zoos try to find where man made mistakes and sometimes meet with success. One of these successes in our zoo is reported in this paper.

\section{BREEDING POLAR BEARS}

Generally the breeding results with Polar Bears in captivity are rather poor. The same den used successfully for Brown Bears is obviously not good enough for Polar Bears. A paper presented at the congress of the International Union of Zoo Directors in Berlin, 1965 on the heating of maternity dens aroused an interesting discussion and revealed a number of unpublished results. Thanks to the cooperation of the following zoos that put their experiences at my disposal this publication is made possible:

Bristol, R. E. Greed

Detroit, K. K. Kreag and K. F. Cline

Milwaukee, G. Speidel

Wuppertal, Dr. R. Müller and Dr. G. Haas

To complete the picture the published results of Bremerhaven (Dr. K. Ehlers) and Nürnberg (Dr. A. Seitz) are added.

As far as possible I tried to summarize the results in tables with some explanatory notes and the details of the isolation dens, as far as available, in simple drawings. Bristol, Wuppertal and Amsterdam are treated separately because there results were obtained by heating the cages. Bedding material was given as straw or straw and shavings. An interesting feature is that the females know how to use this bedding and make a nest (see below).

\section{Isolation dens not heated}

\section{Zoological Park Commission City of Detroit}

Two males and eight females wild-caught in Norway, 1948. Born 1947-48. Isolation dens available for four females only. Cubs born in the exhibit did not survive (except in 1935 to a different group of Polar Bears before maternity cages were built, as two females cared for the same cub). Time of isolation females some time in October (September might be better). 1965 old male removed and wild-caught pair (five years old) added, five raised females were introduced. Number of animals 1966: 1.10. The pregnant females are not individually known. First breeding at 6 years of age.
Table 1. Polar Bear breeding Detroit

\begin{tabular}{|c|c|c|c|c|c|}
\hline \multirow{2}{*}{ Year } & \multirow{2}{*}{$\begin{array}{l}\text { Number } \\
\text { of litters }\end{array}$} & \multicolumn{3}{|c|}{ Number of young born } & \multirow{2}{*}{$\begin{array}{c}\text { Dead } \\
\text { under } \\
3 \text { months }\end{array}$} \\
\hline & & single & twins & total & \\
\hline 1953 & $?$ & $?$ & $?$ & $?$ & all \\
\hline 1954 & 3 & 3 & 0 & 3 & 1 \\
\hline 1955 & 3 & 3 & $\mathbf{0}$ & 3 & 2 \\
\hline 1956 & 4 & 3 & 2 & 5 & $\overline{1}$ \\
\hline 1957 & 2 & 1 & 2 & 3 & 1 \\
\hline 1958 & 2 & $\mathbf{0}$ & 4 & 4 & 1 \\
\hline 1959 & 2 & 2 & $\mathbf{0}$ & 2 & 0 \\
\hline 1961 & 5 & 1 & 8 & 9 & 2 \\
\hline 1962 & 2 & 2 & $\mathbf{0}$ & 2 & 2 \\
\hline 1963 & 3 & 2 & 2 & 4 & 0 \\
\hline 1966 & 3 & 3 & 0 & 3 & $\mathbf{0}$ \\
\hline Total & 29 & 20') & 18 & 38 & 10 \\
\hline
\end{tabular}

1 In seven cases, where young disappeared without the possibility to state the number of cubs, one is recorded. The percentage of death will then be 26 . As about $2 / 5$ of the known litters were twins (13 single - 9 twins) we could presume that this was also the case with the destroyed litters. Then the percentage of losses would be 32 (17 single - 12 twins $=41$ born, 13 dead).

Table 2. Time of birth Detroit

\begin{tabular}{|c|c|c|c|c|c|}
\hline \multicolumn{3}{|c|}{ November } & \multicolumn{3}{c|}{ December } \\
\hline $1-10$ & $11-20$ & $21-30$ & $1-10$ & $11-20$ & $21-31$ \\
\hline 3 & 6 & 10 & 6 & 2 & 1 \\
\hline
\end{tabular}

Not included a cub born in the second part of January; the only cub known to me not born in November or December.

\section{Milwaukee County Park Commission \\ Milwaukee County Zoological Park}

Two males and two females wild-caught in Norway 1912. Born 1911. Isolation dens available for both females. Time of isolation early in October. All animals individually known.

No records being available of three litters - born 1923 (male twins), 1927 (female) and 1933 (male) these are listed as dead under three months although it is probable that they lived. 
Table 3. Polar Bear breeding Milwaukee

\begin{tabular}{|c|c|c|c|c|c|c|c|c|c|c|c|}
\hline \multirow{2}{*}{ Years } & \multirow{2}{*}{$\begin{array}{c}\text { Numb. } \\
\text { of } \\
\text { litters }\end{array}$} & \multicolumn{4}{|c|}{ Young born } & \multirow{2}{*}{$\begin{array}{c}\text { Dead } \\
\text { under } \\
3 \mathrm{~m} .\end{array}$} & \multirow{2}{*}{ Mother } & \multirow{2}{*}{$\begin{array}{l}\text { Born } \\
\text { 1) }\end{array}$} & \multirow{2}{*}{ Father } & \multirow{2}{*}{$\begin{array}{l}\text { Born } \\
\text { 2) }\end{array}$} & \multirow{2}{*}{$\begin{array}{l}\text { Interval } \\
\text { betw. births } \\
\text { in years }\end{array}$} \\
\hline & & $\overline{\text { Single }}$ & Twins & 중? & Total & & & & & & \\
\hline $1919-27$ & 5 & 3 & 4 & $52-$ & 7 & 3 & Sultana I & W. 1911 & Silver King & W. 1911 & 2 \\
\hline $1929-35$ & 4 & 3 & 2 & $32-$ & 5 & 2 & & 然 & Borealis I & 0. & 2 \\
\hline 1944-52 & 5 & 5 & 0 & $32-$ & 5 & 0 & Sultana II & Z.'31 & Borealis II & Z.'29 & 2 \\
\hline 1955 & 1 & 1 & 0 & $10-$ & 1 & 1 & Cirrus & Z. 44 & & $"$ & - \\
\hline $1958-63$ & 3 & 3 & 0 & -12 & 3 & 2 & $"$ & $"$ & Artice & Z. '48 & $\begin{array}{l}\text { twice } 3 \\
\text { once } 2\end{array}$ \\
\hline $1958-61$ & 2 & 2 & 0 & 02 - & 2 & 0 & Miss Bartlett & Z.' 46 & $"$ & $"$ & 3 \\
\hline Total & 20 & 17 & 6 & 1292 & 23 & 8 & \multicolumn{5}{|c|}{ Percentage of death: 35} \\
\hline
\end{tabular}

1) $\mathrm{W}=$ Wild born; $\mathrm{Z}=$ Zoo born.

Table 4. Time of birth Milwaukee

\begin{tabular}{|c|c|c|c|c|c|}
\hline \multicolumn{3}{|c|}{ November } & \multicolumn{3}{c|}{ December } \\
\hline $1-10$ & $11-20$ & $21-30$ & $1-10$ & $11-20$ & $21-31$ \\
\hline 0 & 1 & 7 & 8 & 3 & 1 \\
\hline
\end{tabular}

Tiergrotten Bremerhaven (EmLERS, 1964)

One of the females (Suse II) born 1953-54 bred for den available. No dates available about the females the first time 1958 at an age of 5 years. One isolation Wally and Suse I.

Table 6. Polar Bear breeding Bremerhaven

\begin{tabular}{|c|c|c|c|c|c|c|c|}
\hline \multirow{2}{*}{ Year } & \multirow{2}{*}{$\begin{array}{c}\text { Number } \\
\text { of } \\
\text { litters }\end{array}$} & \multicolumn{3}{|c|}{ Number of young born } & \multirow{2}{*}{$\begin{array}{c}\text { Dead } \\
\text { under } \\
3 \mathrm{~m} .\end{array}$} & \multirow{2}{*}{ Female } & \multirow{2}{*}{$\begin{array}{c}\text { Year } \\
\text { of } \\
\text { birth }\end{array}$} \\
\hline & & single & twins & total & & & \\
\hline $\begin{array}{c}1935 \& 1938 \\
1939-47 \\
1958-61\end{array}$ & $\begin{array}{l}2 \\
7 \\
3\end{array}$ & $\begin{array}{l}2 \\
4 \\
2\end{array}$ & $\begin{array}{l}0 \\
6 \\
2\end{array}$ & $\begin{array}{r}2 \\
10 \\
4\end{array}$ & $\begin{array}{l}2 \\
6 \\
1\end{array}$ & $\begin{array}{c}\text { Wally } \\
\text { Suse } \\
\text { Suse II }\end{array}$ & $\frac{-}{1953}$ \\
\hline Total & 12 & 8 & 8 & 16 & 9 & $\% \mathrm{~d}$ & 56 \\
\hline
\end{tabular}

Table 7. Time of birth Bremerhaven

\begin{tabular}{|c|c|c|c|c|c|}
\hline \multicolumn{3}{|c|}{ November } & \multicolumn{3}{c|}{ December } \\
\hline $1-10$ & $11-20$ & $21-30$ & $1-10$ & $11-20$ & $21-31$ \\
\hline 0 & 2 & 5 & 3 & 1 & 1 \\
\hline
\end{tabular}

Tiergarten Nïrnberg (SEITz, 1952, 1954/56, 1958/ 59)

Two males (since 1948 one) and four females wild caught 1939. Born 1938-39. Isolation dens available for all females but isolation not complete. With two
Table 5. Breeding age of female Polar Bear in years

\begin{tabular}{|l|c|c|}
\hline Name & First born & Last born \\
\hline Sultana I & 8 & 24 \\
Sultana II & 13 & 21 \\
Cirrus & 11 & 19 \\
Miss Bartlett & 12 & 15 \\
\hline
\end{tabular}


E. F. JACOBI

Table 8. Polar Bear breeding Nürnberg

\begin{tabular}{|c|c|c|c|c|c|c|}
\hline \multirow{2}{*}{ Years } & \multirow{2}{*}{$\begin{array}{c}\text { Number of } \\
\text { litters }\end{array}$} & \multicolumn{3}{|c|}{ Number of young born } & Dead under & Female \\
\cline { 3 - 8 } & single & twins & total & months & \\
\hline $1948-55$ & 7 & 0 & 14 & 14 & 3 & 1 (Alma) \\
$1948-55$ & 8 & 2 & 12 & 14 & 14 & 2 (Betti) \\
$1948-55$ & 8 & 1 & 14 & 15 & 12 & 3 (Centa) \\
$1951-55$ & 5 & 0 & 10 & 10 & 6 & 4 (Dora) \\
\hline Total & 28 & 3 & 50 & 53 & 35 & $\%$ death: 66 \\
\hline
\end{tabular}

The number of cubs of five litters born 1953 and 1954 ls not stated. I supposed that these have been twins.

Table 9. Time of birth Nürnberg (21 litters)

\begin{tabular}{|c|c|c|c|c|c|}
\hline \multicolumn{3}{|c|}{ November } & \multicolumn{3}{c|}{ December } \\
\hline $1-10$ & $11-20$ & $21-30$ & $1-10$ & $11-20$ & $21-31$ \\
\hline 0 & 5 & 8 & 5 & 1 & 2 \\
\hline
\end{tabular}

Isolation dens heated

At Amsterdam, Bristol and Wuppertal no Polar Bear cubs survived after birth before electric heating was installed in the isolation den. After this change the same females brought up some of their young. Bristol Zoo was the first to try this practice.

Table 10. Amsterdam, Bristol and Wuppertal (not heated)

\begin{tabular}{|c|c|c|c|c|c|c|c|c|}
\hline \multirow{2}{*}{ Zoo } & \multirow{2}{*}{ Years } & \multirow{2}{*}{$\begin{array}{c}\text { Number of } \\
\text { litters }\end{array}$} & \multicolumn{3}{|c|}{ Number of young born } & \multirow{2}{*}{$\begin{array}{c}\text { Dead } \\
\text { under } \\
3 \mathrm{~m} .\end{array}$} & \multirow{2}{*}{ Mother } & \multirow{2}{*}{$\begin{array}{c}\text { Year of } \\
\text { birth }\end{array}$} \\
\hline & & & single & twins & total & & & \\
\hline $\begin{array}{c}\text { Amsterdam } \\
\text { ", } \\
\text { Bristol } \\
", \\
" \\
\text { Wuppertal } \\
\text { ", }\end{array}$ & $\begin{array}{c}1961 \\
1962-1963 \\
\\
1925 \\
1926 \\
1927-1954 \\
\\
1955-1957 \\
1958-1959 \\
1960\end{array}$ & $\begin{array}{c}1 \\
\text { no births } \\
\text { recorded } \\
1 \\
1 \\
\text { no births } \\
\text { recorded } \\
3 \\
2 \\
1\end{array}$ & $\begin{array}{l}1 \\
- \\
- \\
- \\
- \\
2 \\
2 \\
1\end{array}$ & $\begin{array}{l}- \\
- \\
2 \\
2 \\
- \\
2 \\
- \\
-\end{array}$ & $\begin{array}{l}1 \\
- \\
2 \\
2 \\
- \\
4 \\
2 \\
1\end{array}$ & $\begin{array}{l}1 \\
- \\
2 \\
2 \\
- \\
4 \\
2 \\
1\end{array}$ & $\begin{array}{c}\text { Laila } \\
\text { " } \\
\text { Elizabeth } \\
\text { " } \\
\\
\text { Cynthia } \\
\text { Freya } \\
\text { Frigga }\end{array}$ & $\begin{array}{c}1955 \\
, " \\
\text { not known } \\
, " \\
\\
1946 \\
1952 \\
"\end{array}$ \\
\hline & Total & 9 & 6 & 6 & 12 & 12 & \multicolumn{2}{|c|}{ Death rate $100 \%$} \\
\hline \multicolumn{9}{|c|}{ Same after installation of electric heating } \\
\hline $\begin{array}{c}\text { Amsterdam } \\
\text { Bristol } \\
\text { " } \\
\text { " } \\
\text { Wuppertal } \\
\text { " }\end{array}$ & $\begin{array}{c}1964-1966 \\
1958 \\
\left.1965^{2}\right) \\
1965 \\
1966 \\
1960-1963 \\
1961-1964\end{array}$ & $\begin{array}{l}2 \\
1 \\
1 \\
1 \\
1 \\
1 \\
2\end{array}$ & $\begin{array}{l}2 \\
1 \\
1 \\
1 \\
1 \\
1 \\
1\end{array}$ & $\begin{array}{l}- \\
- \\
- \\
- \\
- \\
2 \\
4\end{array}$ & $\begin{array}{l}2 \\
1 \\
1 \\
1 \\
1 \\
3 \\
5\end{array}$ & $\begin{array}{l}0 \\
0 \\
1 \\
1 \\
0 \\
0 \\
4\end{array}$ & $\begin{array}{c}\text { Laila } \\
\text { Cynthia } \\
\text { N"̈ } \\
\text { F" } \\
\text { Freya } \\
\text { Frigga }\end{array}$ & $\begin{array}{c}\text { 1) } \\
1946 \\
1958 \\
\text { "' } \\
\text { "? }\end{array}$ \\
\hline & Total & 11 & 8 & 6 & 14 & 6 & \multicolumn{2}{|c|}{ Death rate $43 \%$} \\
\hline
\end{tabular}

1) In 1966 possibility of twins but no proof (in that case born 3, raised 2).

2) As male died the breeding came to an end until the male born to Cynthia in 1958 matured.

3) During birth of twins 1964 there was very serious disturbance by building activities. 
Table 11. Time of birth Amsterdam, Bristol, Wuppertal

\begin{tabular}{|c|c|c|c|c|c|}
\hline \multicolumn{3}{|c|}{ November } & \multicolumn{3}{c|}{ December } \\
\hline $1-10$ & $11-20$ & $21-30$ & $1-10$ & $11-20$ & $21-31$ \\
\hline 0 & 1 & 7 & 10 & 1 & 1 \\
\hline
\end{tabular}

The births to Cynthia at Bristol always occured on December 3.

Table 12. Summary of breeding results of Polar Bears

\begin{tabular}{|c|c|c|c|c|c|c|c|c|c|c|c|c|}
\hline \multirow{3}{*}{ Zoo } & \multirow{3}{*}{$\begin{array}{c}\text { Number } \\
\text { of } \\
\text { litters }\end{array}$} & \multicolumn{6}{|c|}{ Period of birth } & \multicolumn{3}{|c|}{ Numb. of young born } & \multirow{3}{*}{$\begin{array}{c}\text { Dead } \\
\text { within } \\
3 \mathrm{~m} .\end{array}$} & \multirow{3}{*}{$\begin{array}{c}\text { Survival } \\
\text { percentage }\end{array}$} \\
\hline & & \multicolumn{3}{|c|}{ November } & \multicolumn{3}{|c|}{ December } & \multirow{2}{*}{ Single } & \multirow{2}{*}{ Twins } & \multirow{2}{*}{ Total } & & \\
\hline & & $1-10$ & $11-20$ & $21-30$ & $1-10$ & $11-20$ & $21-31$ & & & & & \\
\hline Detroit & 29 & 3 & 6 & 10 & 6 & 2 & 1') & 20 & 18 & 38 & 10 & $74(68 ?)$ \\
\hline Milwaukee & 20 & 0 & 1 & 7 & 8 & 3 & 1 & 17 & 6 & 23 & 8 & 65 \\
\hline Bremerhaven & 12 & 0 & 2 & 5 & 3 & 1 & 1 & 8 & 8 & 16 & 9 & 44 \\
\hline Nürnberg & 21 & 0 & 5 & 8 & 5 & 1 & 2 & 3 & 50 & 53 & 35 & 34 \\
\hline Amsterdam & 3 & 0 & 0 & 0 & 3 & $\mathbf{0}$ & $\mathbf{0}$ & 3 & - & 3 & 1 & 67 \\
\hline Bristol & 9 & 0 & 0 & 4 & 5 & $\mathbf{0}$ & $\mathbf{0}$ & 6 & 6 & 12 & 10 & 16 \\
\hline Wuppertal & 8 & $\mathbf{0}$ & 1 & 3 & 2 & 1 & 1 & 5 & 6 & 11 & 7 & 36 \\
\hline Total & 102 & 3 & 15 & 37 & 32 & 8 & 6') & 62 & 94 & 156 & 80 & 49 \\
\hline
\end{tabular}

') and one in January

\section{Description of isolation dens} NOT HEATED

Detroit (fig. 1)

The maternity den is bedded down with 8-10" (20$25 \mathrm{~cm}$ ) of straw and not disturbed until cubs are brought out by mother in early spring. Zoo closes after first Sunday of November (no disturbance by public). As time for birth draws near all disturbances are avoided. Only keepers come in aisle way. Outside temperature during period of birth between $40^{\circ}$ to $-10^{\circ} \mathrm{F}\left(4.5\right.$ to $\left.-23^{\circ} \mathrm{C}\right) .0^{\circ} \mathrm{F}\left(-18^{\circ} \mathrm{C}\right)$ is common during late December and January.

Milwaukee

Speidel states in a letter:

"The breeding dens are approximately $10 \mathrm{ft}$. by $10 \mathrm{ft}$. [3 $\times 3 \mathrm{~m}$ ]. The pregnant bears are separated from the group early in October and are given this very seclusive den.

We have no known temperatures, except no heat is provided. We give them extensive beds of shavings and straw and no one goes near them until the cubs are brought out."

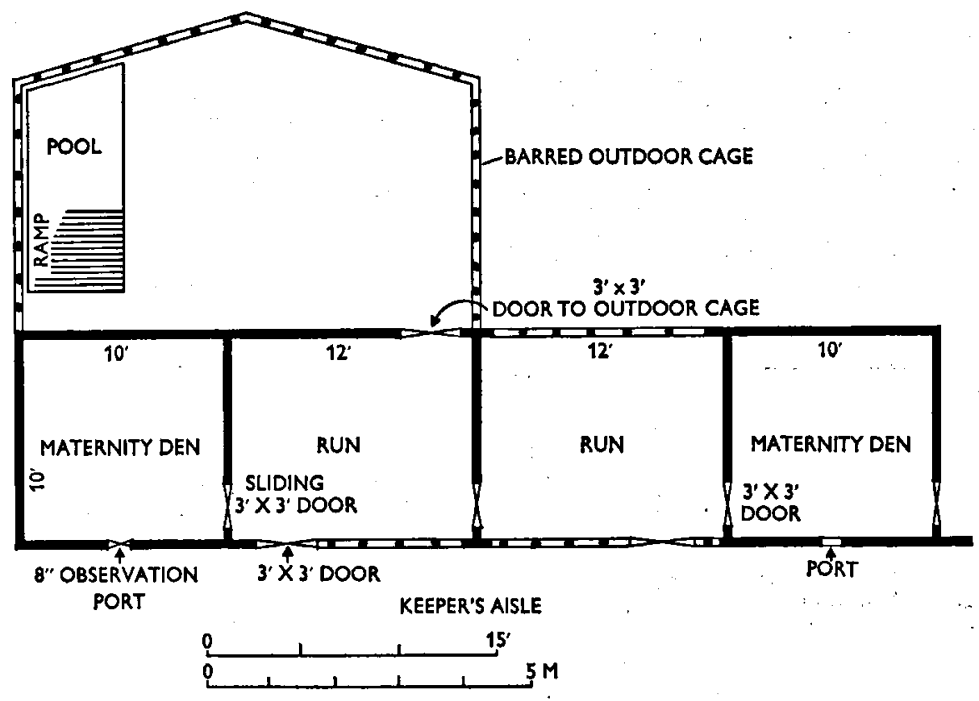

Fig. 1. Detroit. 


\section{Bremerhaven}

One maternity den, separated from the rest, with outside enclosure with bath for female and cubs.

\section{Nürnberg (fig. 2)}

As seen in figure 2 the four dens have no run or outside enclosure for female and cubs.

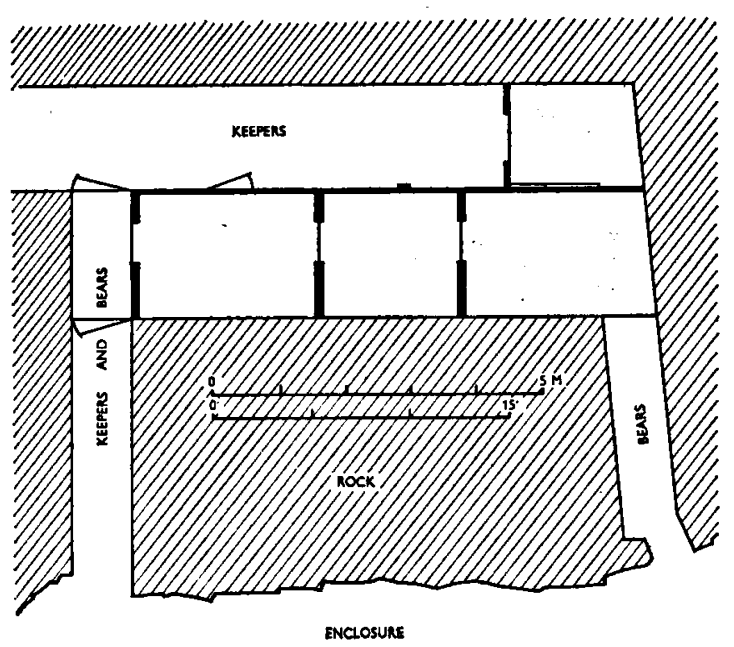

Fig. 2. Nürnberg.

\section{HEATED}

\section{Amsterdam (fig. 3)}

Den not very quiet in centre of building, surrounded by service aisle. Straw bedding is provided. Female very reluctant to enter and for that reason isolation often too late. Radiant heating of $2.5 \mathrm{kw}$, cub born at spot 1964; with $1.6 \mathrm{kw}$ at spot 1966 . Heating $2^{\prime} 5^{\prime \prime}$ $(73 \mathrm{~cm})$ above floor. Temperature in service quarter $40-50^{\circ} \mathrm{F}\left(5-10^{\circ} \mathrm{C}\right)$. Estimated temperature on spot of birth $60^{\circ} \mathrm{F}\left(15^{\circ} \mathrm{C}\right)$. Ventilation: Door $\mathrm{A}$ open on top $10^{\prime \prime}(25 \mathrm{~cm})$, slide B open, bars C closed with a wooden board, with opening of $8^{\prime \prime}(20 \mathrm{~cm})$.

\section{Bristol}

The nursery was built behind a walled-off section of the bears' enclosure where the female was completely isolated but had space for exercise. It was constructed of brick with a concrete roof with an entrance about 2'6" $(75 \mathrm{~cm})$ square and this was never closed - in other words, the nursery was always open to the outside temperature. The mother bear was transferred to the new quarters about 6 weeks before the expected birth and very firm instructions were given that only her keeper would be allowed to go anywhere near the place for the next few months. Electric floor-warming was installed as follows: Cork $\%$ " (19 mm) thick was laid on the floor of the nursery onto which was placed Panelec E Screened P.V.C. $210 \mathrm{~V}$ cable to provide $0.5 \mathrm{kw}$ of heating - the whole area then being covered with $3^{\prime \prime}(7.5 \mathrm{~cm})$ of concrete. A thermostat was installed to maintain a rise in temperature within the enclosure of $15^{\circ} \mathrm{F}\left(8^{\circ} \mathrm{C}\right)$ - to achieve this the thermostat was set to $120^{\circ} \mathrm{F}\left(49^{\circ} \mathrm{C}\right)$. Straw bedding was provided, but only a small amount was found in the nursery at the end of 3 months. Likewise with the second successful birth.

\section{Wuppertal (fig. 4)}

Despite good isolation and heavy straw bedding no cubs were reared before heating was installed. Radiant electric heating $2 \times 750 \mathrm{w}(1.5 \mathrm{kw}), 5^{\prime}$ (150 $\mathrm{cm})$ above floor.

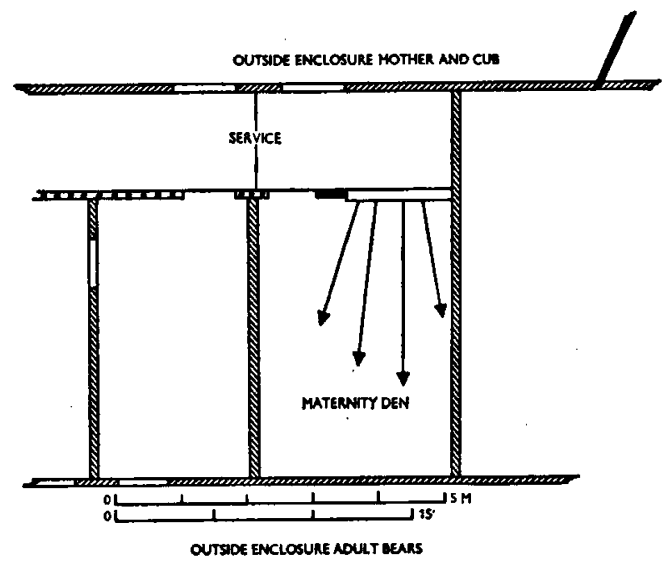

Fig. 4. Wuppertal.

Fig. 3. Amsterdam. 


\section{DISCUSSION AND CONCLUSIONS}

The main breeding results with Polar Bears in captivity, even taking into consideration the "successes" described above, are not satisfactory. Only the best results obtained, with a survival percentage of the cubs between 60 and 70, can be accepted as good. A very important factor in obtaining this result are the maternity dens. In nature (Wrangel Island, Gerald Island, Tchuktschen Peninsula; UsPENSKr, 1967) pregnant females mostly dig a small hole in last year's snow on east or north slopes, mostly not more than 5 miles $(8 \mathrm{~km})$ from the coast. Slopes with an incline of 25-45 degrees are preferred. The new snow buries the female. The result is a maternity den $6^{\prime} 6^{\prime \prime}-8^{\prime} 4^{\prime \prime}(2-2.5 \mathrm{~m})$ long and $5^{\prime}(1.5 \mathrm{~m})$ wide and high with a narrow tunnel connecting it with the open air. On favourable places there will be up to three dens on 250 acres (a square kilometre).

In all cases females in captivity know how to make a nest by arranging bedding provided, even if this is given at one side of the den after the female has entered into it. For this reason it is to be expected that the floor of the den in the wild will often be the normal vegetation or that plant material is brought in afterwards, even if Uspenski's description does not hint this. From the experiences and figures stated I would conclude that the best facilities are:

A very seclusive maternity den with only one door. This door leads to a run where water and food can be provided and this again to an outside enclosure. Results can be expected with a den and run or a den and outside enclosure only, the lack of disturbance being the most important factor. If the accommodation is completely accepted the bear can shelter the cub effectively against rather low temperature. If, for some reason, the female does not stay with the cub an electric heating (floor heating to about $60^{\circ} \mathrm{F}$ $\left(15^{\circ} \mathrm{C}\right)$ or radiant heating of 1.5 up to $2 \mathrm{kw}$ ) may keep it warm while she is away so it will behave normally when she returns and will not catch a cold. This factor might be of special importance during the first 6-8 weeks after birth.

The measurements of the den are of secundary importance but the danger of it being too large is, I think, greater than that of it being too small. Good dimensions are: maternity den $6^{\prime}$ to $7^{\prime}$ (175 to 200 $\mathrm{cm})$ square, run 7' $(200 \mathrm{~cm})$ square or larger, outside enclosure with bath. When constructing new dens it seems advisable to install heating from the beginning as this seems more safe.

Other conclusions from the above data are that the time of birth (table 12) is November-December, with a peak between 11th November and 11th December (84 of 102 births). DitTrich (1961) collected data from literature and gives the following figures with part of the Nürnberg figures which are also included in our figures.

Table 13. Time of birth according to Dittrich

\begin{tabular}{|c|c|c|c|c|c|}
\hline \multicolumn{3}{|c|}{ November } & \multicolumn{3}{c|}{ December } \\
\hline $1-10$ & $11-20$ & $21-30$ & $1-10$ & $11-20$ & $21-31$ \\
\hline 3 & 20 & 27 & 40 & 19 & 10 \\
\hline
\end{tabular}

USPENSKI (1967) states as time of birth in the wild state December to January, without giving information how this conclusion is reached. It seems probable that the difference between captivity and the wild state is less marked.

About the number of young in the wild the same author states (in translation): "Normally there are two cubs. Three is rare and the younger females have only one". More data must be available but I could not find them. In captivity a triplet seems never to have occurred.

About the age of the female when she gives birth for the first time it may be presumed that 5 years is a minimum (Bremerhaven 1958), as Uspenski states for the wild bears. The oldest female to give birth in my figures is 24 years (Milwaukee, Sultana I).

\section{SUMMARY}

The breeding results of Polar Bears in captivity are in general very disappointing. Unsuitable maternity dens are the main cause. These should be completely closed, very quiet without outside disturbances and should have connection with a run and thus with an outside enclosure. The female should be isolated in this den a month before birth and be provided with heavy bedding. She should not be disturbed before she comes out with her cubs in early spring. Electric heating in this den (floor or radiant) can be of advantage and in some cases means the difference between failure and success. The time of birth is November and December with a peak in the last decade of November (table 12) or one in the first decade of December (table 13). The number of young in captivity is mostly one and often two (table 12: 62 single, 47 twins born). The female is capable of giving birth at the age of $\mathbf{5}$ and can have cubs at least till 24 years of age. If the cubs are taken from the mother at about 15 months she can breed every two years, which is normal zoo practice. 


\section{ZUSAMMENFASSUNG}

Die Eisbärenzucht in Gefangenschaft ist im Allgemeinen schlecht. Hauptursache sind meist ungeeignete Zuchtkäfige. Wichtigste Voraussetzung ist, jede Störung von aussen $\mathrm{zu}$ vermeiden, der Zuchtkäfig muss absolut ruhig sein und sollte Zugang zu einem offeneren, geräumigeren Innenkäfig haben, dieser wiederum sollte mit einer Freianlage (bzw. Aussenkäfig) mit Bad verbunden sein. Die Bärin sollte einen Monat vor dem Werfen in diesem Käfig isoliert werden und reichlich Stroh zur Verfügung haben. Sie sollte dann nicht gestört werden, bis sie selbst mit den Jungen im Vorfrühling den Zuchtkäfig verlässt. Elektrische Heizung im Wurfstall (Boden- oder Strahlungsheizung) kann wichtig sein und in Einzelfällen über Erfolg oder Misserfolg entscheiden. Die Geburtszeit fällt in die Monate November, Dezember, mit einem Gipfel in der letzten Dekade des November (Tabelle 12), oder in der ersten Dekade des Dezember (Tabelle 13). In Zoologischen Gärten wird meistens ein einzelnes Jungtier geboren; oft aber auch Zwillinge. (Tabelle 12: 62 Einlinge, 47 Zwillinge). Die Eisbärin züchtet vom 5. Lebensjahr an bis zum 24. Lebensjahr. Wenn die Jungen nach 15 Monaten abgesetzt werden, kann sie in Abständen von zwei Jahren züchten, was normale Zoopraxis ist.

\section{RESUME}

L'élevage des Ours Polaires en captivité est généralement décevant. La cause principale est la mauvaise constitution des cages de maternité. Dans ces cages la femelle doit être tranquille et à l'abri des perturbations exterieures; chacune de ces cages doit communiquer avec une seconde cage plus découverte donnant accès à un enclos contenant un bassin. Un mois avant la naissance l'ourse doit être isolée dans cette cage, où elle doit disposer d'une épaisse couche de paille. Elle ne doit point être dérangée jusqu'au moment où elle sort par elle-même avec ses enfants dans l'avant-printemps. Le chauffage électrique (du sol ou radiant) est important et, dans quelques cas, peut déterminer le succès ou l'échec. Les naissances ont lieu en novembre ou décembre, avec une fréquence maximum dans la dernière décade de novembre (Table 12) ou dans la première décade de décembre (Table 13). En captivité on observe généralement un seul ourson mais les jumeaux ne sont pas rares (Table 12: 62 seuls et 47 jumeaux). La femelle procrée dès l'âge de 5 ans jusqu'à l'âge de 24 ans. Les jeunes sont sevrés à l'âge de 15 mois, les femelles sont donc capables de procréer tous les deux ans, ceci étant une règle générale dans les parcs zoologiques.

\section{LITERATURE}

For general references see Dittrich, 1961.

AfONSKAJA, R. I. and KRUMINA, M. K., 1958: Observations on Polar Bears. Moskovskij Zoopark, Sbornik Statej 2, 56 (Russian. Summary: Zool. Garten 17, 1963, 302).

Ditrrich, L., 1961: Zur Werfzeit des Eisbären (Ursus maritimus). Säugetierk. Mitt. 9, 12.

EHLERS, K., 1964: Sorgen mit Eisbärennachwuchs. Zool. Garten 29, 231.

Kostuan, E. J., 1934: Eisbären und Wachstum. Zool. Garten 7, 157.

OuWehand, C. W., 1939/40: Ueber Geburt und Jugendentwicklung eines Eisbären. Zool. Garten 11, 102.
SEITZ, A., 1952: Eisbärenzucht in Nürnberger Tiergarten. Zool. Garten 19, 180.

- 1954/56: Eisbärzucht 1952 in Nümberg. Zool. Garten 21,161 .

- 1958/59: Nürnberg. Jahresbericht 1955. Zool. Garten 24, 128.

USPENSKI, SAWAA, 1967: Eisbären genau auf dem Nordpol. Das Tier 8, 16.

VoLF, Jı̌̌, 1963: Einige Bemerkungen zur Aufzucht von Eisbären (Thalarctos maritimus) in Gefangenschaft. Zool. Garten 28, 97.

- 1963: Bemerkungen zur Fortpflanzungsbiologie der Eisbären Thalarctos maritimus (Phipps) in Gefangenschaft. Zeitschr. Säugetierk. 28, 163. 